SUS-RURI: Proceedings of a Workshop on Developing a Convergence Sustainable Urban Systems Agenda for Redesigning the Urban-Rural Interface along the Mississippi River Watershed held in Ames, lowa, August 12-13, 2019

\title{
Reconciling Climate Change with Nitrate Impairment of Drinking Water: Policies for lowa's Largest City
}

Christopher S. Jones ${ }^{1}$, Silvia Secchi ${ }^{1}$

${ }^{1}$ University of lowa

Published on: Dec 24, 2019

DOI: 10.31274/3d9ea6a4.b72d61d0

License: Creative Commons Attribution 4.0 International License (CC-BY 4.0). 
The Raccoon River watershed of Central Iowa has been the focus of intense research because of its role as a source supply for municipal drinking water (Jones et al., 2016). Climate in the watershed is characterized by warm, humid summers and cold, dry winters. The watershed lies within the prairie pothole ecoregion, an area with some of the most extreme and dynamic climate on earth (Winter 1989; Woodhouse and Overpeck 1998; Ahrens 2007). Agriculture is the predominant land use throughout the catchment with row crops of corn and soybean comprising nearly $80 \%$ of the basin (Jones and Schilling, 2011). This, along with high-density livestock production, has elevated stream nitrate levels and impaired the mainstem river for the downstream drinking water utility (Des Moines Water Works - DMWW), which provides treated water to over 500,000 people. The Raccoon has the highest nitrate concentration of any of the 42 largest tributaries draining to the Mississippi River (Goolsby et al. 2000).

What might climate change mean for stream nitrate loads? In the Raccoon River watershed, precipitation has increased about 25\% since 1916. This, coupled with land use change (artificial drainage and conversion of native perennial plants to annual crops) has increased average streamflow (discharge) in the river about $250 \%$ over the same time period. Thus we know that the relationship between precipitation and discharge is not linear, i.e. $100 \mathrm{~mm}$ of increased precipitation can produce far more than $100 \mathrm{~mm}$ of increased discharge (normalized to watershed area).

We also know that the relationship between nitrate loads and river discharge is nearly linear, i.e. if discharge doubles, nitrate loads will likely double, on average. So if Iowa continues to get wetter, which many climate experts predict, relatively modest increases in precipitation could result in disproportionately large increases in nitrate loss from farm fields.

It is likely that annual precipitation will continue to increase in the coming decades in the artificially-drained agriculture area of the U.S. Midwest. Easterling and Karl (2001) estimate this increase may be as high as $20-40 \%$ by year 2100 in this area. These changes in climate can be expected to impact subsurface hydrology and crop production, and subsequently motivate farmers to enlarge the capacity of constructed drainage systems (Singh et al., 2009), which are the primary source of stream nitrate. Regional climatic models nested into a global model predicted 24 to $32 \%$ increase in annual average precipitation and a 2.3 to $2.7 \mathrm{oC}$ increase in temperature (compared to the 1990s) by 2050 for Perry, Iowa (Singh et al., 2009), a city lying near the center of 
the watershed. Any increase in temperature could also be expected to increase the supply of soil nitrate resulting from mineralization, as this is a temperature-dependent process (DeNeve et al., 2003). It seems very likely this new scenario will increase flux of nitrate from the watershed. How the agricultural producers and the downstream utility react to these changes will be critical if safe water is to be provided to the nearly $20 \%$ of Iowa's population receiving water from DMWW.

There are a variety of policy approaches that could be used to address this problem. One often cited example is New York City's Watershed Agricultural Program. The city compensates farmers in the Delaware and Catskill watersheds, which provide its drinking water, for activities that reduce water pollution (Grolleau \& McCann, 2012; Kousky, 2015). The program pays for easements to retire land out of production but also for Best Management Practices on working lands. The rationale is that it is much cheaper to compensate farmers to reduce their pollution ex ante than to build water treatment facilities for the city. This is an example of Payments for Ecosystem Services (PES), which are policy tools that assume that the right to pollute rests with the polluters. An alternative approach that uses another economic instrument would be to tax pollution-generating inputs, since taxing pollution itself can be very complicated and expensive in agriculture. Though examples of these policies are less common, the Danish pesticide tax case illustrates how such an approach could be implemented (Pedersen, Nielsen, \& Andersen, 2015). Taxing pollution generating activities presumes that the pollutees (in this case the residents of Des Moines) have the right to clean water, and that the polluter pays principle applies. This is one of the guiding principles of the Organization for Economic Co-operation and Development, though agriculture has often been considered a legitimate exception to it (Stevens, 1993). An alternative to taxes and subsidies, which both operate by changing incentives for farmers, is to use Command and Control (CAC) policies. These could range from restrictions on practices on working lands (such as the fall application of fertilizer) to mandating land uses (such as forcing farmers not to grow annual crops next to streams). There are few examples of CAC policies in agriculture (Shortle \& Abler, 2001), but pesticide bans are an example. They have been implemented in the US as recently as 2017, when Arkansas banned Dicamba (Knox, 2018). Hybrid approaches that combine a mix of regulatory and incentive-based tools are also possible. Such approaches form the core of the new Common Agricultural Policy in the European Union, and consist of farm-level payments decoupled from the production of agricultural commodities, with the payments dependent on farmers following environmental guidelines (OECD, 2015; Pe'er et al., 2014). Thus, a variety of policy 
tools are available. As one of us noted almost 10 years ago, "ultimately, the choice of mechanisms to achieve the social goal of higher environmental quality while preserving rural vitality will be dependent on political expediency and what is feasible rather than optimal." (Secchi \& Soman, 2010).

Climate change impacts on both rural and urban watershed residents may provide the impetus to implement some of these approaches in the Raccoon River Watershed. While the specific policy approach remains unclear, it is apparent that it will require collaboration across the rural-urban divide, be nested within the Mississippi River Basin, and address the potential for unintended consequences (such as reducing rural economic activity) and potential co-benefits. For example, land use changes in the Raccoon to reduce nutrient losses could help mitigate floods. It is also apparent that credible facilitators, multiple stakeholders and disciplines will have to be involvedranging from rural sociologists to hydrologists-to ensure both the legitimacy of the approach and its scientific credibility.

\section{Citations}

Ahrens, C.D. (2007). Meteorology today: an introduction to weather, climate, and the environment. 8th Ed. Thompson: Brooks/Cole.

De Neve, S., Hartmann, R., Hofman, G. (2003). Temperature effects on N mineralization: changes in soil solution composition and determination of temperature coefficients by TDR. Eur. J. Soil Sci., 54, 49-62.

Easterling, D.R., Karl, T.R. (2001). Potential consequences of climate variability and change for the Midwestern United States. Report Prepared for the US Global Change Research Program, 167188.

Goolsby, D. A., Battaglin, W. A., Aulenbach, B. T., \& Hooper, R. P. (2000). Nitrogen flux and sources in the Mississippi River Basin. Science of The Total Environment, 248(2-

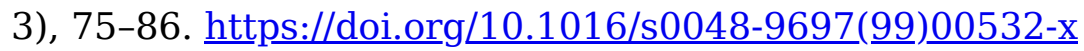

Grolleau, G., \& McCann, L. M. J. (2012). Designing watershed programs to pay farmers for water quality services: Case studies of Munich and New York City. Ecological Economics, 76, 87-94. https://doi.org/10.1016/j.ecolecon.2012.02.006.

Jones, C. S., \& Schilling, K. E. (2011). From Agricultural Intensification to Conservation: Sediment Transport in the Raccoon River, Iowa, 1916-2009. Journal of Environment Quality, 40(6), 1911. https://doi.org/10.2134/jeq2010.0507 
Jones, C. S., Seeman, A., Kyveryga, P. M., Schilling, K. E., Kiel, A., Chan, K.-S., \& Wolter, C. F. (2016). Crop rotation and Raccoon River nitrate. Journal of Soil and Water Conservation, 71(3), 206-219. https://doi.org/10.2489/jswc.71.3.206.

Knox, J. F. (2018). Sowing the Seeds of Controversy: What the Dicamba Debacle Reveals about the Modern Pesticide Registration Process and Why the EPA Must Act. Environmental Law, 48(4), 835-874.

Kousky, C. (2015). New York City's Watershed Agricultural Program. In M. Lago, J. Mysiak, C. M. Gómez, G. Delacámara, \& A. Maziotis (Eds.), Use of Economic Instruments in Water Policy (pp. 351-363): Springer.

OECD. (2015). Public Goods and Externalities: Agri-environmental Policy Measures in Selected OECD Countries. Paris, France: OECD Publishing.

Pe'er, G., Dicks, L. V., Visconti, P., Arlettaz, R., Báldi, A., Benton, T. G., . . Scott, A. V. (2014). EU agricultural reform fails on biodiversity. Science, 344(6188), 1090-1092. https://doi.org/10.1126/science.1253425.

Pedersen, A. B., Nielsen, H. Ø., \& Andersen, M. S. (2015). The Danish Pesticide Tax. In M. Lago, J. Mysiak, C. M. Gómez, G. Delacámara, \& A. Maziotis (Eds.), Use of Economic Instruments in Water Policy (pp. 73-88): Springer.

Secchi, S., \& Soman, S. (2010). Mandatory and voluntary conservation policies: Competing visions or complementary approaches? In T. Napier (Ed.), Human dimensions of soil and water conservation: A global perspective. New York, NY: Nova Science Publishers.

Shortle, J. S., \& Abler, D. G. (2001). Environmental policies for agricultural pollution control: CABI.

Stevens, C. (1993). The OECD guiding principles revisited. Environmental Law, 23(2), 607-619.

Singh, R., Helmers, M.J., Kaleita, A.L., Takle, E.S. (2009). Potential impact of climate change on subsurface drainage in Iowa's subsurface drained landscapes. J. Irrig. Drain. Div., Am. Soc. Civ. Eng. 135, 459466.

Winter, T.C. (1989). Hydrologic studies of wetlands in the northern prairie. In van der Valk, A., ed. Northern Prairie wetlands, 16-54. Iowa State University Press, Ames, IA. 
Woodhouse, C.A., Overpeck, J.T. (1998). 2000 years of drought variability in the central United States. Bull. Am. Meteorol. Soc. 79, 2693-2714.

Christopher S. Jones, Research Engineer, IIHR Hydroscience and Engineering Silvia Secchi, Associate Professor, Geographical and Sustainability Sciences University of Iowa

This event is supported by the National Science Foundation, Award \#1929601. Any opinions, findings, and conclusions or recommendations expressed in this material are those of the author(s) and do not necessarily reflect the views of the National Science Foundation. 